\title{
ECONOMICS
}

\section{ELECTRICITY MARKET INTEGRATION GLOBAL TRENDS AND IMPLICATIONS FOR THE EAS REGION}

by

\author{
Yanrui Wu
}

Business School University of Western Australia 


\title{
ELECTRICITY MARKET INTEGRATION: GLOBAL TRENDS AND IMPLICATIONS FOR THE EAS REGION
}

\author{
YANRUI WU \\ Economics, Business School, University of Western Australia
}

DISCUSSION PAPER 12.19

\begin{abstract}
Electricity market reform has been implemented in many countries and regions in the world. There is no doubt that electricity consumption continues to increase in East Asia. Electricity market integration in East Asia is thus an important component of the energy market integration (EMI) initiatives supported by the East Asian Summit (EAS) group. It is argued that an integrated East Asian electricity market would allow consumers to have access to competing suppliers within or beyond the borders and enable electricity providers in member economies to better deal with peak demand and supply security. The objectives of this study are twofold, namely, a) to present a review of the trends in regional electricity market integration and b) to draw implications for electricity market development in the EAS area. Specifically, this project will review the trends of integration in the world's major electricity markets and analyze the experience and lessons in those markets. It will provide an examination of the electricity sectors in East Asia in terms of market development and connectivity. It will provide policy recommendations for the promotion of electricity market integration.
\end{abstract}

Keywords: Electricity market integration, Energy market, EAS region.

JEL Classification: Q40, Q48

Acknowledgement: This report is part of the outcomes of the project on Energy Market Integration in East Asia: Theories, Electricity Sector and Subsidies conducted by Economic Research Institute for ASEAN and East Asia (ERIA). I am grateful for the financial support provided by ERIA. I thank Fukunari Kimura, Youngho Chang, Xunpeng Shi (project coordinator) two anonymous project team members and participants of two workshops at ERIA for helpful comments and suggestions. 


\section{Introduction}

In the coming decades world demand for electricity is projected to have an average annual rate of growth of $2.3 \%$ which exceeds the growth rate (1.6\%) of total energy use globally (EIA 2011a). Thus the electricity sector plays an important role in promoting energy market integration (EMI) in the East Asian Summit (EAS) region. This report aims to present a brief review of the world's major electricity markets and global trends towards market integration. The findings are employed to draw implications for electricity market integration in the EAS area. The rest of the report begins with an overview of electricity demand in the world in Section 2. This is followed by discussions about the trends of electricity sector reforms and hence market integration initiatives in Section 3. Subsequently electricity markets in the EAS region are examined in Section 4. Policy recommendations are presented in Section 5 with the final section presenting concluding remarks (Section 6).

\section{Global Electricity Demand}

Electricity consumption in the world has maintained a steady growth trend in recent decades (Figure 1). Total consumption almost doubled between 1990 and 2011. During the same period, the Asia Pacific region has overtaken Europe and North America to become the largest electricity consumer (Figure 2). In 2010 the United States was still the largest single consumer with a share of $20.3 \%$ over the world total while China was just behind the US with a share of 19.7\%. By 2011 China overtook the US to become the world's largest electricity user as well as producer with a share of $21.3 \%$ while the US share continuously declined to $19.6 \%$. Japan is the third largest consumer with a share of about $5 \%$ followed by Russia $\left(4^{\text {th }}\right)$ and India $\left(5^{\text {th }}\right)$. 


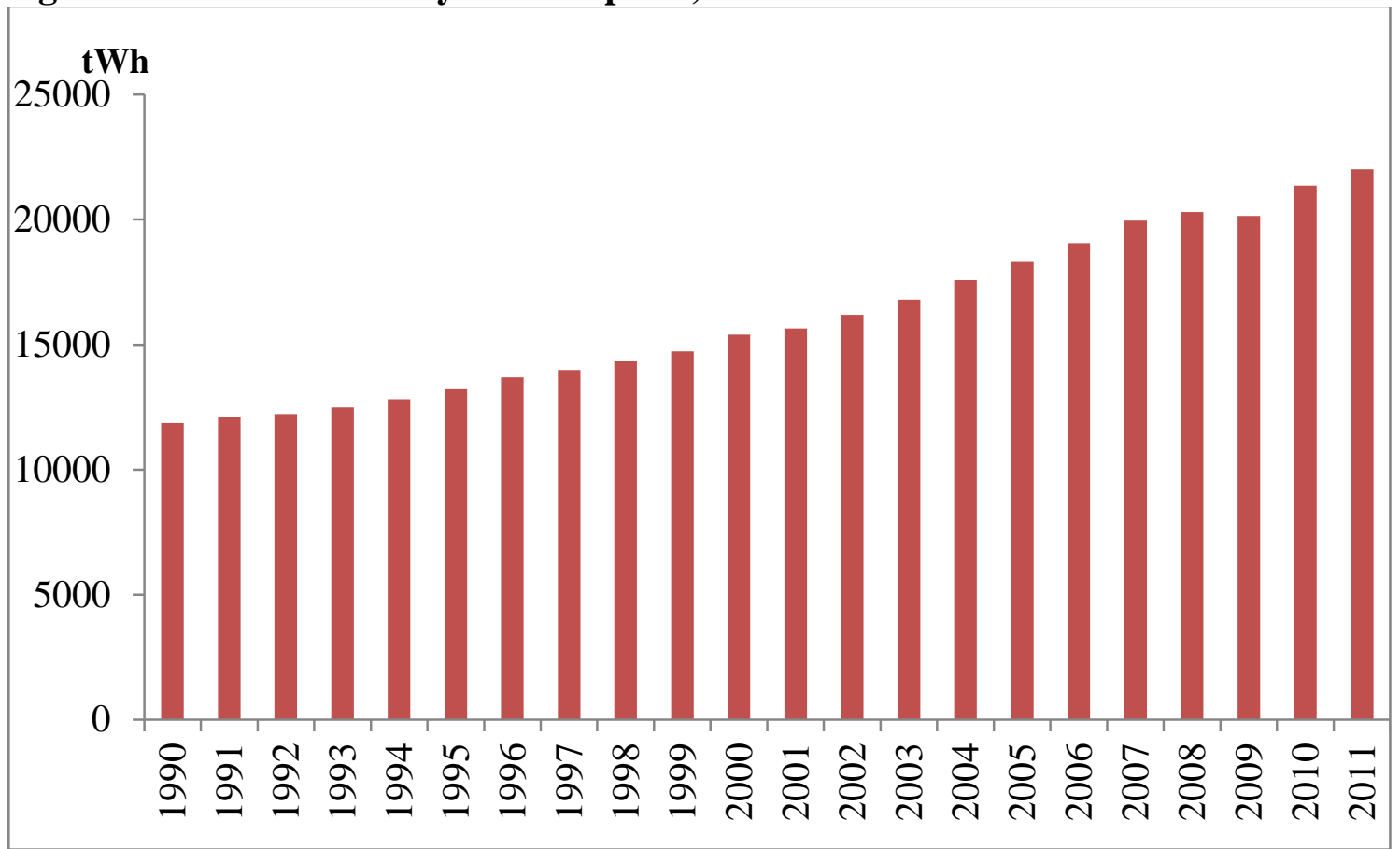

Notes: The unit is terawatt hours (tWh).The raw data are drawn from BP (2012).

Figure 2: Electricity Consumption Shares by Regions, 1990 and 2011

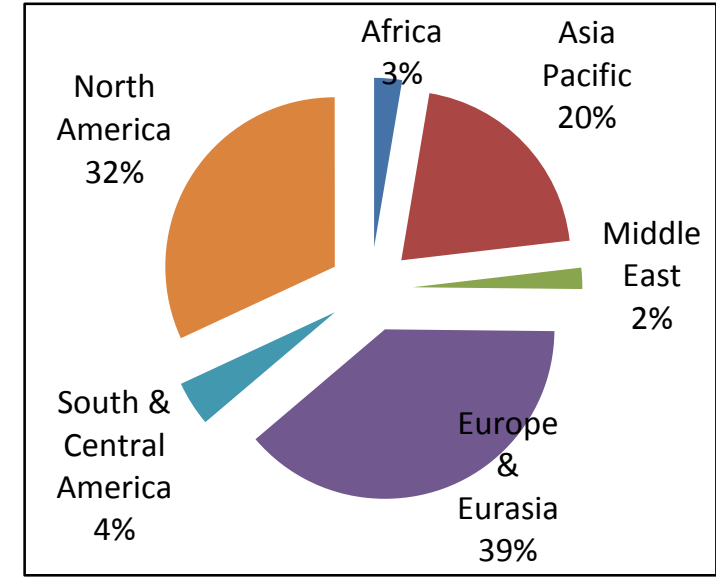

1990

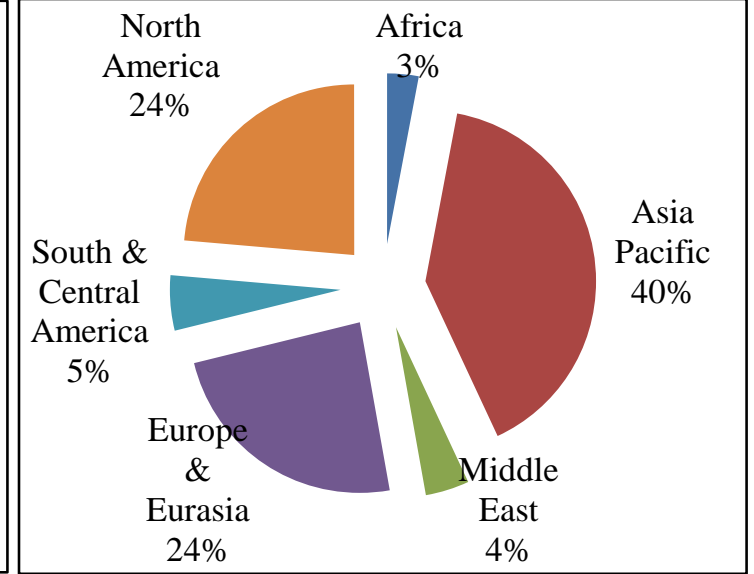

2011

Notes: The raw data are drawn from BP (2012).

At the sector level, the industrial sector is still the largest electricity consumer in the world with a share of 40.2\% in 2009 (IEA 2011). This figure, however, varies 
considerably across the countries ranging from $26 \%$ in the US to $39 \%$ in India and $74 \%$ in China (Table 1). The general trend is that electricity consumption shares have declined in major developed economies due to the delocalization of manufacturing activities, the growth of commercial and public service sectors and increasing ownership of appliances and electronic equipment in households. For example, among IEA member economies, the share of industrial electricity consumption declined from $49 \%$ in 1974 to $33 \%$ in 2007, with the US having the smallest industrial share among the members (IEA 2009a). Residential consumption shares vary from 39\% in the US to 24\% in India and 12\% in China (Table 1). Agriculture and transportation are included in the "others" category in Table 1. These two sectors generally account for small shares in electricity consumption in major economies. There are however exceptions. For example, agricultural consumption of electricity reported in Table 1 has a share of 19\% in India (CSO 2012).

Table 1: Electricity Consumption Shares (\%) by Sector in Selected Economies

\begin{tabular}{lllll}
\hline Sectors & IEA & China & India & US \\
\cline { 2 - 5 } & $(2007)$ & $(2010)$ & $(2010)$ & $(2010)$ \\
\hline \hline Industrial & 33 & 74 & 39 & 26 \\
Residential & 31 & 12 & 24 & 39 \\
Commercial & 31 & 6 & 10 & 35 \\
Others & 5 & 8 & 27 & 0 \\
\hline
\end{tabular}

Notes: Indian data cover the 2010/2011 financial year. Data are drawn from NSBC (2012), CSO (2012), EIA (2012) and IEA (2009a).

Electricity generation is still dominated by coal (40\%) followed in turn by natural gas, renewables, nuclear and liquids (Figure 3). This pattern will probably remain for a long time. According to EIA (2011a), by 2030, the share of coal in electricity generation will decline slightly (36\%) and the winners will be renewables (24\%) and natural gas (24\%) with nuclear power remaining the same (14\%) and the share of liquids shrinking to about $2 \%$. 
Figure 3: Sources of Electricity Generation in the World, 2008

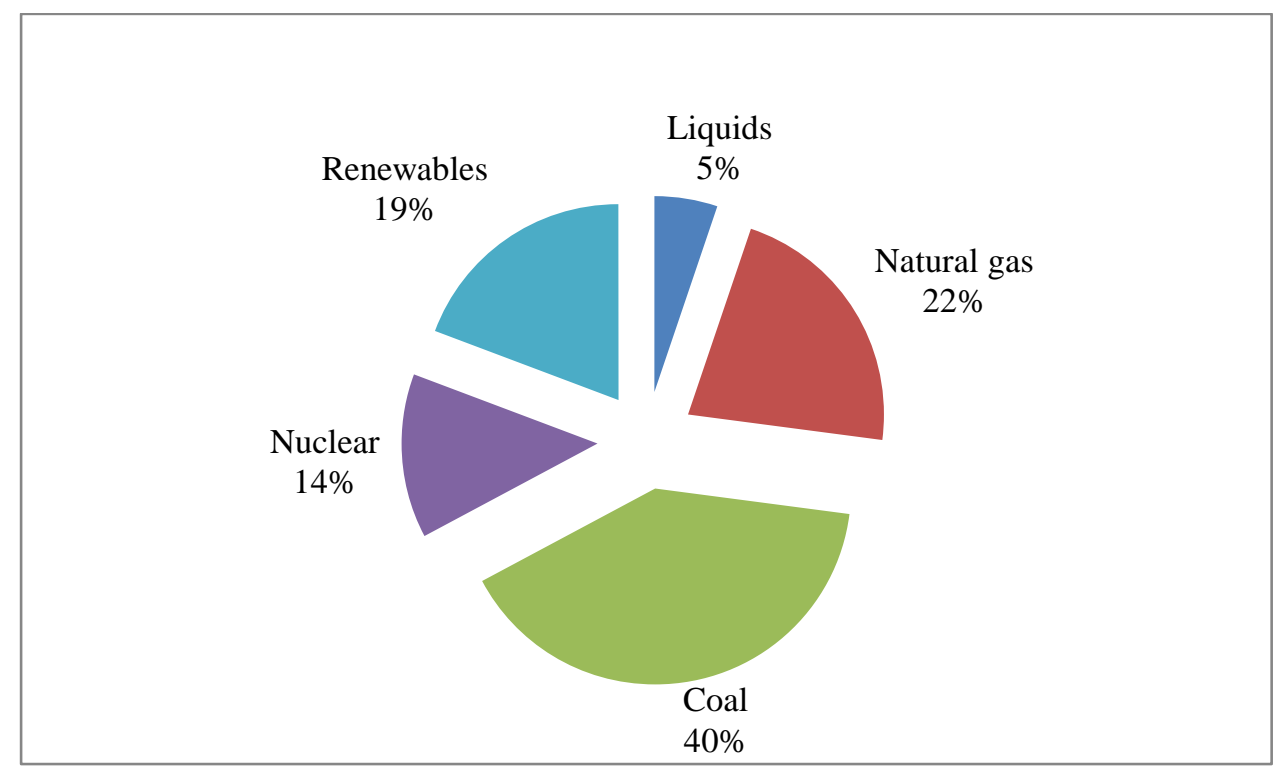

Source: EIA (2011a).

\section{Trends in Market Integration}

It has been argued that an integrated electricity market can improve efficiency in electricity supply, reduce costs of production and hence electricity prices, and raise standards of services due to increased competition. As global concerns for climate change increase, regional power integration could be an effective way to reduce carbon emissions (Zhai, 2010). Following these arguments, various policy measures have been implemented in order to promote national and regional electricity market integration. The progress of changes varies among the major markets. The large markets include the European Union (EU) and the United States (US). The relatively successful examples of small economies include Chile, New Zealand and Singapore. The reforms have led to the formation of national electricity markets in some countries such as Australia, Norway and the UK. In some regions cross-border trade has emerged through different kinds of cross-border access arrangements such as the FranceBelgium-Netherlands connection and the Nordic market (Norway, Sweden, Finland and Denmark). Though electricity market integration has been challenged due to events 
such as the California electricity crises during 2000-01 and the 2003 New York black out, reforms are still debated and implemented in different forms (Kwoka, 2006).

Chile was the world's first country introducing reforms in the electricity sector in 1982 (Nagayama, 2011). Chile’s reform has been hailed as a successful example (IEA 2009b). The main law that governs the electricity sector in Chile is the General Electric Services Law of 1982, which was amended in 2004 and 2005, respectively. Enactment of the law in 1982 led to the vertical and horizontal unbundling of the electricity sector. The process of privatization of state-owned utilities began in 1986 and was completed in 1998. Together with privatization was the establishment of a spot market for electricity and a contract market in which generators and large industrial users could trade freely. The electricity market in Chile is now characterized with free competition in generation and distribution while transmission is still regulated. Reforms have led to growth in Chile's electricity sector for about two decades. But major blackouts and some other problems did occur. Therefore, Chile's electricity sector is still facing some challenges and possibly further reforms. For example, Pollitt (2005) pointed out the need to improve the transparency of the regulation and oversight of the industry and the inflexibility in regulations governing the power sector due to overly detailed specifications.

The UK was one of the first European countries to embark upon reforms of the electricity sectors. In 1989 the Electricity Act was enacted to introduce competition in power generation and electricity wholesale in the UK. By the implementation of the Electricity Act 2000, a highly competitive electricity market was to emerge. In March 2001 NETA (the new electricity trading arrangements) was introduced for wholesale trading. There were about 40 power producers competing in the markets compared to seven in 1990 (EA, 2002). The three regions in the UK used to be covered by three markets which were separated up until 2005 (Pond, 2006). In April 2005 NETA was replaced by BETTA (British electricity transmission and trading arrangements) to accommodate the interconnection with the power grid of Scotland (Giulietti, et al. 2010). Deregulation progress in the UK electricity market is now well ahead of the rest of Europe. Since deregulation the market has performed well. The generation sector has maintained an adequate margin of spare capacity and electricity prices have been comparatively low and fairly responsive to the movements in fuel prices (DECC, 2010). 
Sweeting (2007) constructed the Herfindahl-Hirschman index to show that competition in generation is indeed enhanced.

Before 1978 the US electricity market was dominated by large, vertically integrated utilities. To create an integrated electricity market, deregulation began with the issue of the Public Utility Regulatory Policies Act (PURPA) in 1978. The initial reform targeted at the wholesale sector and aimed to promote the wholesale power transactions between utilities. By the 1990s, further reforms were introduced and a deregulated industry took shape. For example, non-discriminatory open access was protected through the promulgation of the Energy Policy Act 1992 and later the FERC Orders 1996. ${ }^{1}$ The system was further improved through the introduction of regional transmission organizations (RTOs) under FERC Order 2000. RTOs are empowered to operate the transmission lines on behalf of all market participants. By 2000 more than half the states either had restructured their electricity sectors or were planning to do so though changes varied across the states. An important factor that influences tariff levels in the US is the mix of energy sources used in power generation. For example, access to cheap federal power from hydropower plants contributes to low electricity tariffs in some states. In the aftermath of the California blackout, the pace of reform has slowed.

Chile, the UK and US are good examples of successfully developing a nationally integrated electricity market through several phases. In recent years a lot of efforts have also been made to develop sub-regional electricity markets through cross-border connections and trading. One of the earlier initiatives was the establishment of the Nord Pool which interconnects the national grids of Norway, Sweden, Finland and Denmark. Since its launch in the 1990s the Nord Pool has evolved into a well-integrated and efficient wholesale market though retail markets still remain national markets in these countries. In 2006 France, Belgium and the Netherlands also launched the TLC market. Germany and Luxemburg later joined this interconnected market. A late comer was the interconnection between Spain and Portugal launched in 2007. In other continents, the six states of the Gulf Cooperation Council (GCC) formed their interconnection authority in 2001. The final interconnection work is supposed to be completed by 2013.

\footnotetext{
${ }^{1}$ FERC is short for the Federal Energy Regulatory Commission.
} 
Regional electricity market integration has been promoted by nations in the world, including countries in the EAS area. The actual progress in interconnection varies across the continents. The major initiatives so far share some commonalities. First, interconnections mainly occur among neighboring countries which have well-developed national markets. Second, sub-regional markets are outgrowth of bilateral electricity exchanges. Finally, market integration is accompanied with domestic reforms and international harmonization of regulations standards. These observations have important implications for the development of integrated electricity market in the EAS region.

\section{Electricity Markets in the EAS Region}

The EAS economies as a group amounted to about $19 \%$ of the world's total electricity consumption in 1990 (Table 2). This share almost doubled by 2010 (36\%) and will maintain a modest growth in the coming decades according to predictions (ADB, 2009). In terms of market integration, most EAS members are yet to develop a national electricity market. Cross-border trading is still at the early stage of development. In general the 16 member countries can be broadly divided into several groups in accordance with their market and institutional development.

Due to different stages of economic development, EAS members have made different progress in electricity market development. Relatively mature and integrated national markets have emerged in several EAS countries, namely, Australia, New Zealand and Singapore. Some members are at various stages of developing a national electricity market (Brunei, China, Japan, Malaysia, the Philippines, South Korea, Thailand and Viet Nam). Others are still trying to improve the level of electrification in their societies (India, Indonesia, Cambodia, Laos and Myanmar). In terms of the integration and unbundling of business activities, namely, generation (G), transmission (T), distribution (D) and retailing (R), the sixteen EAS members are broadly divided into four groups (Figure 4). Each of them is discussed in the following text. 
Table 2: Electricity Demand in EAS Economies

\begin{tabular}{|c|c|c|c|}
\hline Countries & 1990 & 2011 & 2030 \\
\hline Australia & 156 & 264 & 367 \\
\hline Brunei & 1 & 3 & 4 \\
\hline Cambodia & 1 & 2 & 13 \\
\hline China & 621 & 4700 & 6374 \\
\hline India & 284 & 1006 & 2414 \\
\hline Indonesia & 33 & 182 & 318 \\
\hline Japan & 841 & 1104 & 1324 \\
\hline Lao PDR & 1 & 7 & 60 \\
\hline Malaysia & 25 & 119 & 265 \\
\hline Myanmar & 2 & 9 & 56 \\
\hline New Zealand & 32 & 43 & 64 \\
\hline Philippines & 26 & 69 & 165 \\
\hline Singapore & 16 & 46 & 105 \\
\hline South Korea & 118 & 520 & 624 \\
\hline Thailand & 44 & 152 & 400 \\
\hline Vietnam & 9 & 111 & 235 \\
\hline EAS & 2211 & 8338 & 12783 \\
\hline World & 11861 & 22018 & 31779 \\
\hline EAS/World(\%) & 19 & 38 & 40 \\
\hline
\end{tabular}

Notes: Demand is expressed in terawatt hours (tWh). The raw data are drawn from BP (2012) for 1990 and 2011 and ADB (2009) for 2030. Data for Brunei, Cambodia, Laos and Myanmar are author's own estimates.

The Singapore public utilities board (PUB) has been the sole provider of electricity until 1995 when the regulatory roles were separated from businesses by corporatizing electricity supplies under Singapore Power. In 2001 Energy market authority (EMA) was established to become the industry regulator. Since then competition has been introduced into generation and wholesale and retailing to large electricity users though transmission is regulated. Further reform is to deregulate the retail market of small users. According to Tan (2008), deregulation has provided power companies the incentives to reduce costs by using cheap fuels, adopting cost competitive technologies and hedging against volatility in fuel prices. Tan also observed that the rise in electricity tariffs has been significantly smaller than oil price increases since deregulation. However Chang (2007) argued that the deregulated electricity sector in Singapore is only marginally competitive. 
Figure 4: Electricity Market Development Status of EAS Members

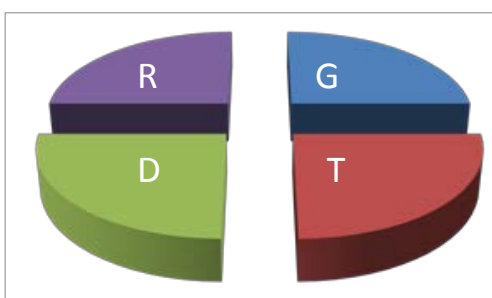

(Australia, New Zealand \& Singapore)
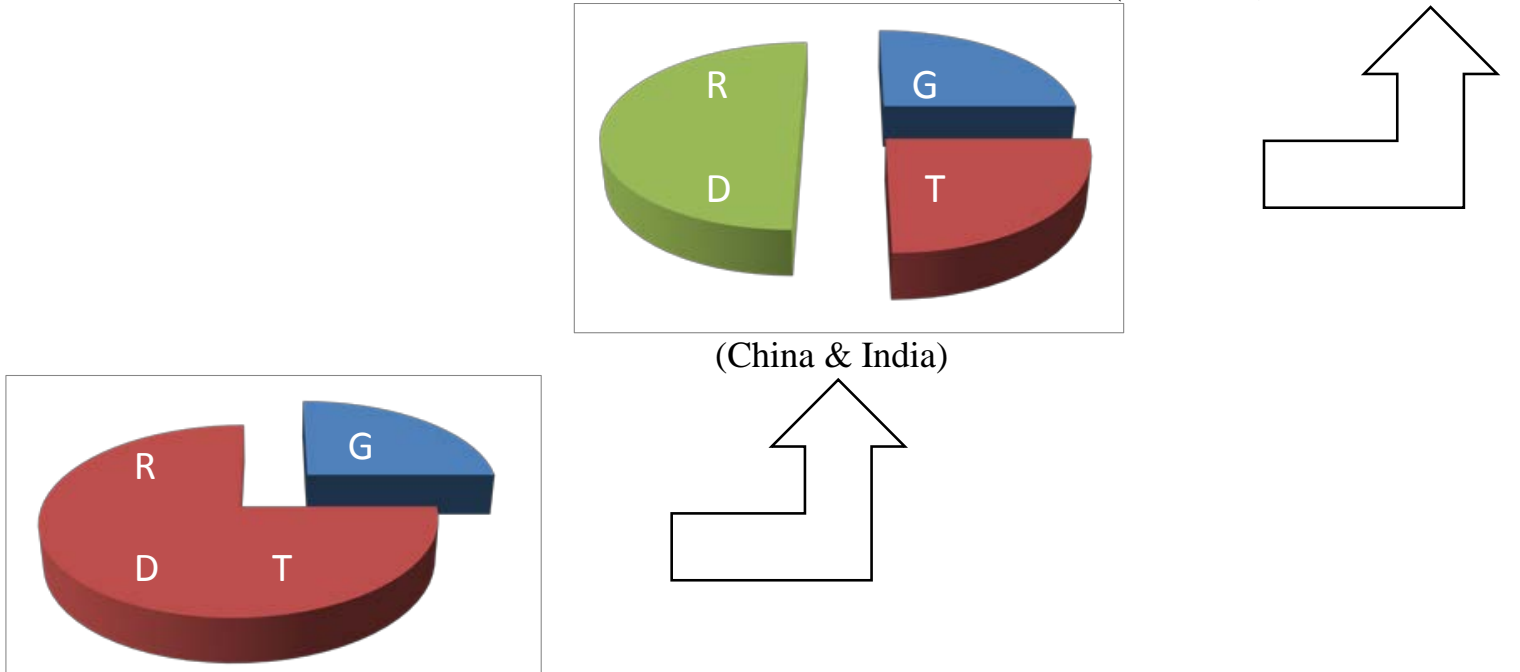

(Cambodia, Indonesia, Japan, Korea, Laos, Malaysia, Myanmar, Philippines \& Vietnam)
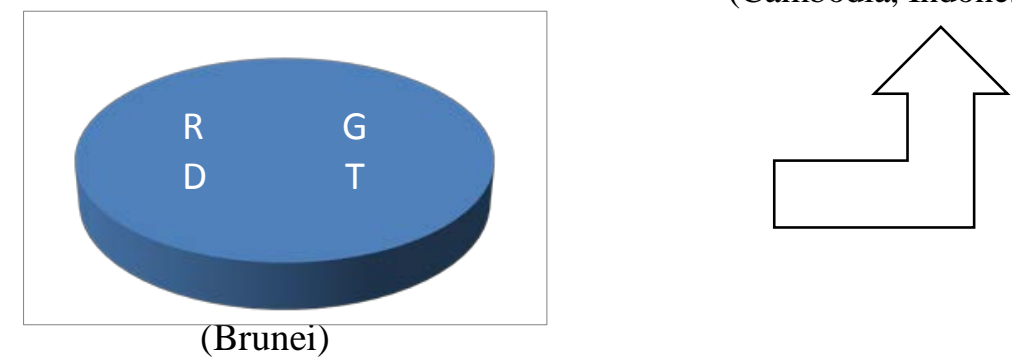

Source: Author's own work. 
The Australian electricity sector used to be dominated by vertically integrated businesses operating in each state. These businesses were government owned and operated monopolies and interconnection between the states virtually did not exist. The restructuring reform began with the separation of the contestable generation and retail services from the non-contestable transmission and distribution services in the early 1990s. The National Electricity Market (NEM) was formally established and commenced operation in December 1998 under the rules of the National Electricity Code. Further reforms led to the issue of the National Electricity Rules authorized by the National Electricity Law in July 2005. Electricity sector reform in Western Australia began with the disaggregation of Western Power (the State monopoly) into four state-owned companies in April 2006. Subsequently, the Wholesale Electricity Market (WEM) was established in September 2006. Since then, the WEM has facilitated competition and promoted private investment in the generation and retail sectors of the electricity industry in Western Australia. The electricity market in Australia is now divided geographically into two deregulated markets, namely, the NEM and WEM. The NEM covers the Southern and Eastern Australia and has a market share of $89 \%$ while the WEM has a market share of $10 \%$ (Davidson 2010). In the NEM areas, generators compete for the right to supply electricity; there is open access to the grid for new generation; and customers are free to choose who supplies their electricity. In the small WEM, competition exists mainly in the generation sector.

The electricity industry in New Zealand was one of the pioneers undertaking deregulation and reforms. In April 1987, the state-owned Electricity Corporation of New Zealand Ltd (ECNZ) was established (Shen \& Yang 2012). In May 1993, ECNZ’s transmission businesses were set up as a separate transmission company, Transpower. Five years later, the Electricity Industry Reform Act 1998 was enacted to introduce competition in generation and retailing. Under this Act, joint ownership of the electricity distribution businesses and energy businesses (generation and retailing) is prohibited. The Act also guided the split of ECNZ into three state owned generators in 1998. Due to public complaints about high wholesale and retail electricity prices, a review of the electricity sector was conducted in 2009. This review and its recommendations led to the enactment of Electricity Industry Reform Act 2010. One of the major changes was to allow joint ownership of generation and retailing businesses 
(or gentailors). Currently, the New Zealand electricity market has five large gentailors (Shen \& Yang 2012).

IPPs were first introduced into China's electricity sector in 1985. By the end of the 1990s over a half of the electricity supply was generated by non-state owned units (Du, et al. 2009). Genuine competition in generation was limited until the corporatization of state generation and transmission assets in 2002 and the formation of the regulatory body, the State Electricity Regulatory Commission (SERC) in the same year (Gao \& Van Biesebroeck, 2011). Further reforms were implemented to split the former State Power Company (SPC) into two transmission companies and five generation corporations. There is now some competition in generation and free bidding for transmission access has been pilot-tested (Shi, 2012). However distribution and retailing are still regulated. The process of reforms has been slowed down, especially since the power crises in the US. Further moves are still being debated.

India's electricity sector has traditionally been segmented across the states and hence controlled by the State Electricity Boards (SEBs). The government-owned Power Grid Corporation of India Limited (PGCIL) is now working to integrate the regional grids into a national one (Kumar, 2010). Reforms of the vertically integrated SEBs began after the 1991 balance of payment crisis in India. Private participation in the power sector has been encouraged since then. Steps have also been taken to corporatize and unbundle the SEBs. These include the establishment of the independent Electricity Regulatory Commissions in 1998 and the enactment of Electricity Act 2003. However, implementation of reforms has been very slow. By June 2012 the private sector only had a capacity share of 27.75\% (Ministry of Power, 2012). SEBs used to be the sole purchasers of power. Since January 2009, open access has become possible for all users. Several options of power trading are now available, namely, bilateral trading, unscheduled interchange, national level power exchange and third party sales (PWC, 2009). Bilateral trading still dominates with a share of $48 \%$.

For decades Japan's electricity sector has been monopolized by ten regional electric power companies responsible for regional generation, transmission, distribution and retailing and for coordinating national interconnection (FEPCJ, 2011). The government amended the Electricity Utilities Industry Law (EUIL) in 1995. Subsequently the IPPs entered the market. In 1999 the EUIL was amended again to allow for partial 
deregulation of retail power supply for extra high voltage users (2 megawatts) starting in March 2000 (Goto \& Sueyoshi 2009). In June 2003 the EUIL was further amended to accommodate the extension of reforms in the following years. For example the partial liberalization in 2000 has been extended to medium-sized users (50 kilowatts) since April 2005. However further reforms were halted in 2008 after an industry policy review and will not be reconsidered until the next review in approximately five years (in 2013). In the aftermath of the 2011 Fukushima tragedy, urgent changes in the Japanese electricity sector have been voiced and new reforms may be introduced sooner (Nagayama, 2011).

South Korea's electricity sector has been monopolized by the state-owned Korea Electric Power Corporation (KEPCO). In the aftermath of the 1997 Asian financial crisis, KEPCO’s generation business was split into six separate power companies in 2001. In the same year IPPs were allowed to enter the sector and the Korea Electric Power Exchange (KPX) was established. The original plan of reforms is to privatize the six generation companies and to introduce completion in both generation and distribution. However, further reforms have been delayed. By 2008 KEPCO's subsidiary companies still had a generation share of 82\% (EIA 2011b). KEPCO still controls the country's electricity transmission, distribution and retailing (Kim \& Kim 2008). Thus competition is very limited in the entire electricity sector in South Korea.

In 1992 the Thai government for the first time legalized the participation of the independent power producers (IPPs) in the electricity sector. Since then several attempts under various governments have been made to deregulate the electricity sector. They were all unsuccessful (Nikomborirak \& Manachotphong, 2007). Recent reform initiatives include the release of the Energy Industry Act in December 2007 and subsequently the establishment of the energy regulatory commission (ERC). There are, however, some major difficulties in introducing competition into the electricity sector (Wisuttisak, 2012). The electricity sector in Thailand is still dominated by the stateowned Electricity Generating Authority of Thailand (EGAT). By 2011 EGAT had a market share of $47 \%$ followed by the IPPs (39\%), small power producers (SPPs) (7\%) and imports (7\%). Under the government regulations, EGAT as the largest generator also has the sole right to purchase power from other private producers including neighbouring countries. The EGAT is also the only firm permitted to supply electricity 
to the distributors and retailers. Thus, there is no competition in the wholesale electricity market in Thailand. For the distribution and retail sectors, the markets are also under the monopoly of Provincial Electricity Authority of Thailand (PEA) and Metropolitan Electricity Authority of Thailand (MEA).

The Indonesian power sector is dominated by the state-owned Perusahaan Listrik Negara (PLN). In 1992 the first IPP was approved after the passing of the 1985 Electricity Law in Indonesia. But reforms in the electricity sector have been interrupted by the 1997 Asian financial crisis and subsequently, political instability. By 2009 the IPPs had a market share of about one-sixth (Purra, 2010). Over time the Electricity Law has been revised several times (1999 and 2002). More recently the passing of the 2009 Electricity Law offers some degree of freedom to local governments in dealing with IPPs and setting tariff rates. In terms of regulatory reforms, Purra (2010) argued that the 2009 Law offers very little.

The Philippines was one of the first Southeast Asian countries to allow IPPs with the first IPP contract signed in 1989. In 2001, about 41 per cent of electricity is produced by the IPPs and the rest by the National Power Corporation (NAPOCOR) in the Philippines (Nikomborirak \& Manachotphong, 2007). There is very little competition in the wholesale market. In 2001, a full privatization agenda covering unbundling generation, transmission, distribution, and retail services was approved by the government through the Electricity Power Industry Reform Act (EPIRA). By 2007, the National Transmission Company (TRANSCO) was separated from NAPOCOR. Both TRANSCO and NAPOCOR are supposed to be privatized, but the implementation has been delayed.

Malaysian electricity sector used to be controlled by a vertically integrated system. Reform in this sector has been implemented since the passing of the Electricity Supply Act 1990 and corporatization of the national electricity board in the same year (Fong 2007). IPPs entered the generation businesses in 1993. However deregulation has been interrupted due to power crisis in the 1990s. There is still monopoly in power purchase, transmission and distribution in the Malaysian electricity sector (See, 2011).

The electricity sector of Brunei Darussalam is guided by the Electricity Act 1973 and recently by the Electricity Act (amendment) Order 2002. The business activities are controlled by two state agencies, namely, the Department of Electrical Services 
(www.des.gov.bn) and Berakas Power Company (BPC). Electricity is generated through seven power stations maintained by the two agencies (ED, 2007).

Vietnam, as a relatively low income EAS member, has enjoyed the fastest growth in the rate of electrification in recent years. In March 2004 the first IPP started production in Vietnam (Lovells, 2009). The country's generation capacity however cannot meet the burgeoning demand. As a result an ambitious electricity reform program has been initiated. The purpose of the reform is to achieve full power market liberalization through a gradual three-stage transition. The starting point was the passing of the country's Electricity Law in 2005. Due to this legislation, competition was initially introduced into power generation in 2007 and hence Gencos are allowed to sell to a single buyer (stage I). Further deregulation in the wholesale sector is expected to commence in 2014 (stage II) and a fully deregulated power sector including retailing competition may be realized in 2024 (stage III).

Several EAS members with relatively low income, namely Cambodia, Laos and Myanmar, are still in the process of expanding electrification in their economies. In general, the rate of electrification is still low in those economies but is growing. For example, it expanded from 16\% in 1995 to about 63\% in 2009 in Laos (Bambawale, et al. 2011). According to the World Bank (2012), the rate of electrification in 2009 was only 13\% in Myanmar and 24\% in Cambodia. The immediate task for governments in these countries is to expand electricity access and hence eventually develop a national grid. The private sector is already participating in these fledgling electricity markets. Poch \& Tuy (2012) reported that about 91\% of electricity supply in Phnom Penh, Cambodia, was generated by IPPs in 2010. Cambodia, Laos and Myanmar are also engaged in cross-border trade in electricity with neighboring countries.

\section{Towards an Integrated Electricity Market in the EAS Area}

In order to promote an integrated electricity market within the EAS area, the first step is to achieve cross-border interconnectivity. Over the years, two initiatives have emerged. That is, the development of the ASEAN Power Grid (APG) and Greater Mekong Subregional (GMS) connectivity. APG was proposed as part of the plan to establish an 
ASEAN Economic Community (AEC) by 2015. Through the coordination of the heads of ASEAN power utilities or authorities (HAPUA), some cross-border connectivity has been achieved since the implementation of AIM I (ASEAN interconnection master plan study 2003). Under AIM II (ASEAN interconnection master plan study 2010), nine projects are expected to be completed by 2015 and six more after 2015 (Table 3).

Table 3: ASEAN Power Grid Interconnections

\begin{tabular}{lcc}
\hline Connections & No. of Projects & Capacity (MW) \\
\hline \hline Thailand-Malaysia & 2 & 380 \\
Thailand-Lao PDR & 4 & 1853 \\
Singapore-Malaysia & 2 & 400 \\
Cambodia-Vietnam & 1 & 135 \\
Thailand-Cambodia & 1 & 80 \\
\hline
\end{tabular}

Source: Hermawanto (2011).

In 2002 countries in the greater Mekong sub-region (GMS) also signed an intergovernmental agreement on regional power trade (IGA). In the following year (2003) a regional power trade coordination committee (RPTCC) was formed. One of the tasks of RPTCC is to investigate options for a future GMS power market. By 2012 a formal market is yet to emerge. Some analysts have called for the development of a new GMS strategy (2012-2022) (Baardesen, 2012). Though the process is slow, some connectivity is already achieved among the GMS economies (including Cambodia, China's Yunnan province, Lao PDR, Myanmar, Thailand and Vietnam). For example, China started exporting electricity to Vietnam in 2004. Total exports through seven lines reached 5.5 billion kWh in 2010 (Xinhua, 2011). According to the same source, it was reported that China also started importing electricity from Myanmar in 2008 and a total of 1.7 billion kWh was imported in 2010. China's exports to Lao PDR started in 2009. Apart from the connectivity identified in Table 3, there are also interconnections between Cambodia and Laos (155 kV grid) and between Vietnam and Laos. In the lower Mekong region, both Vietnam and Thailand are net importers of electricity while Laos is a net exporter. In 2007 electricity exports from the Laos amounted to $11.6 \%$ of the country's export revenues (ICEM, 2010). Cambodian electricity imports amount to 385 million kWh from Thailand and 1162 million kWh from Vietnam in 2010 (Poch \& Tuy, 2012). 
These two sources combined account for about $60 \%$ of total electricity consumption in Cambodia.

In general there is still a long way to go in terms of interconnectivity and trade in the EAS electricity sector. EAS is also lagging behind Europe where physical crossborder exchanges have increased from $7.6 \%$ of electricity consumption in 1998 to $10.3 \%$ in 2005 (Meeus \& Belmans, 2008). The development of regional markets such as the GMS market and APG is a necessary interim stage of market integration. In the EAS area, other regional interconnections have also been proposed. These include potential interconnections between Japan and South Korea to deal with emergence (Tanaka 2012) and trade with Russia (von Hippel, et al. 2011) and between India and Myanmar (World Bank, 2007).

While governments in the EAS countries have moved in the right direction to promote market integration in the electricity sector, much more work is needed. Especially, government policies should focus on the development of national electricity markets, the promotion of sub-regional connectivity and power market, harmonization of regulations and standards and coordination in power sector investment and planning. Each of these is discussed next.

\section{National market development}

The rate of electrification in several EAS members is still very low. Apart from the very low electrification rates in Myanmar and Cambodia (under 30\%), access to electricity in India, Indonesia and Lao PDR is also limited (under 70\%). Therefore, the policy priority in these countries is to invest in infrastructure and hence ensure equity in electricity access. For other EAS members with almost universal access, their policy priority is to develop a national grid and hence to achieve nationwide interconnectivity. The formation of national markets is a prerequisite for sub-regional and regional electricity market integration. With the realization of a national market, many countries have initiated reforms of their electricity sectors. Though reform progress varies, the purposes of reforms are the same, namely the introduction of competition into the traditionally state-controlled sector, the improvement in the security and sufficiency of electricity supply, and the encouragement of private sector participation in the electricity businesses. Members who have implemented reforms should continue the 
course and those without reforms should identify the appropriate policy options. The selection of the reform approach and pace is important for a country to truly realize the benefits of changes as there are many examples of failures and successes in the world (Bacon \& Besan-Jones 2001, Zhang, et al. 2008 and Erdogdu, 2012).

\section{Sub-regional connectivity and power market}

Bilateral or sub-regional interconnection becomes possible even if individual members' national markets are not fully developed yet. Member countries can gain and learn from sub-regional cooperation and electricity trading. The experience could be valuable for eventual market integration within the region. For example, it is argued that the long-term goal of buyers and sellers competing across national borders and without constraints (like cross-border commodity trade) has been elusive (Bannister, et al. 2008). However such a goal may be achievable if only two or a small number of countries are engaged. It has been suggested that bilateral trade could be pilot-tested (Antikainen, et al. 2011). In the future the gained experience can be adopted by other groups. The current discussion and development of the GMS power market and APG are the right things to do. Other initiatives could include the establishment of smallscaled power exchanges near border areas and cross-border grids with synchronized operation to exploit peak loads in different time (Baardsen, 2012). A sub-regional approach can also make the best use of different energy resources in a region and contribute to the sustainable management of resources. This is particularly so for hydropower which may use water from the same river system such as the Mekong river. A sub-regional approach can also accommodate the diversity of member economies in terms of economic, regulatory and power sector development.

\section{Harmonization of regulations and standards}

To achieve the goal of an integrated electricity market in the EAS area, members should work together to harmonize regulations and technical standards. The eventual goal is to identify regional best practice and catch up with the global one. Specifically, an integrated regional electricity market needs harmonized regulations and standards associated with 
O consumer protection and safety standards

o legal and tax issues

o standardized contract forms

o tariff-setting mechanism

0 trading systems

\section{Coordination in electricity policies and planning}

The strategy of establishing a regional integrated electricity market should be reflected in individual members' domestic policies and planning in power sector investment and development. Thus members should coordinate to utilize the existing resources efficiently and develop new infrastructures strategically in the future. For example, domestic projects near the border areas could be developed for both domestic and cross-border trading. Other areas for coordination include:

o cross-border investment in the electricity sector

o cross-border licensing

o distribution of generators near border areas

0 information exchanges

o management of shared river resources

\section{Conclusion}

Growth in electricity demand in the world will outpace the growth of world energy consumption in the coming decades. The EAS economies currently account for about one third of the world's total electricity consumption. This share is to grow modestly in the future. Thus electricity market integration has become an important part of the overall goal of developing an integrated energy market in the EAS area. Though major initiatives have been made to promote cross-border electricity trade and hence regional market integration, an integrated EAS electricity market is still a long way to go. Member economies have made various levels of progress towards market development, deregulation and interconnections. Much more work is however needed. Specifically many EAS members should focus on the development of national electricity markets 
and hence achieve the goal of internal market integration. Relatively more developed members could explore the possibility of sub-regional interconnection and development of cross-border power markets (such as the greater Mekong sub-regional connectivity and ASEAN power grid). In order to prepare for eventual regional integration, members should work together to harmonize regulatory standards and rules. Finally members should coordinate in national policy making and development planning in the electricity sector so as to achieve efficient allocation of resources and investment at the national level as well as within the EAS area. 


\section{References}

ADB (2009), Energy Outlook for Asia and the Pacific, October, Manila: Asian Development Bank.

Antikainen, J., R.Gebert and U. Møller (2011), 'Review of the Greater Mekong SubRegion Regional Power Trade’, Sida Review 2011(9), Stockholm: Swedish International Development Cooperation Agency.

Baardesen, E. M. (2012), 'Towards the Sustainability of Hydropower in the Mekong Region: Options for Improved Design and Technologies', presentation slides, Bangkok, 16-17 February.

Bacon, R. W. and J. Besant-Jones (2001), 'Global Electric Power Reform, Privatization and Liberalization of the Electric Power Industry in Developing Countries', Annual Reviews Energy \& the Environment 26, pp. 331-359.

Bambawale, M. J., A. L. D'Agostinoand and B. K. Sovacool (2011), 'Realizing Rural Electrification in Southeast Asia: Lessons from Laos’, Energy for Sustainable Development 15(1), pp.41-48.

Bannister, H., G. McDonell, S. Thorncraft, X. Hu, B. Whitlock and C. Malik (2008), Energy Market Integration in the East Asia Summit Region, REPSF II Project No. 07/005, Jakarta; ASEAN Secretariat.

BP (2012), BP Statistical Review of World Energy 2012, June, London: BP.

Chang, Y. (2007), 'The New electricity Market of Singapore: Regulatory Framework, Market Power and Competition’, Energy Policy 35, pp.403-412.

CEE (2001), 'Results of Electricity Sector Restructuring in Argentina', unpublished case study, Center for Energy Economics, Austin: The University of Texas.

CSO (2012), Energy Statistics 2012, Central Statistics Office, New Delhi: Government of India (india.gov.in).

CTE (2011), 'Thai Power Sector', Publication of Chandler \& Thong-ek Law Offices Limited March 2011, Bangkok: CTE.

Davidson, M.(2010), ‘Australian Electricity Market Overview’, Wessex Consult. Belair: Wessex Consult Pty Ltd, SA, Australia.

DECC (2010), Electricity Market Reform Consultation Document, London: Department of Energy and Climate Change.

Du, L., J. Mao and J. Shi (2009), 'Assessing the Impact of Regulatory Reforms on China's Electricity Generation Industry’, Energy Policy 37(2), pp.712-720.

EA (2002), 'Introduction to the UK Electricity Industry', Electricity Association. London: EA. Utilities [online] Available at: www.u-ol.co.uk/Data Sheets/Intro_UK_Elec_Ind.pdf.

ED (2007), Energy in Brief, Prime Minister's office, Brunei Darussalam. Bandar Seri Begawan: Energy Division. 
EIA (2011a), International Energy Outlook 2011, Washington D. C: U.S. Energy Information Administration. Available at: www.eia.gov.

EIA (2011b), Country Analysis Briefs: South Korea, Washington D. C.: U.S. Energy Information Administration. Available at: www.eia.gov.

EIA (2012), Electricity Explained, U.S. Washington D. C.: Energy Information Administration. Available at: www.eia.gov.

Erdogdu, E. (2012), 'The Political Economy of Electricity Market Liberalization: A Cross-country Approach', Cambridge Working Papers in Economics 1227, Cambridge: Faculty of Economics, University of Cambridge.

FEPCJ (2011), Electricity Review Japan, Tokyo: Federation of Electricity Power Companies of Japan.

Fong, Cheong May (2007), 'Regulation of the Electricity Industry in Malaysia', The Antitrust Bulletin 54(1), pp.67-86.

Gao, H. and J. Van Biesebroeck (2011), 'Effects of Deregulation and Vertical Unbundling on the Performance of China's Electricity Generation Sector', Discussions Paper Series (DPS) 11.30, Leuven: Center for Economic Studies, Katholieke Universiteit.

Giulietti, M., L. Grossi and M. Waterson (2010), 'Price Transmission in the UK Electricity Market: Was NETA Beneficial?’, Energy Economics 32(5), pp.11651174.

Goto, Mika and Toshiyuki Sueyoshi (2009), 'Productivity Growth and Deregulation of Japanese Electricity Distribution’, Energy Policy 37(8), pp.3130-3138.

Hermawanto, B. (2011), 'Report of the $8^{\text {th }}$ Meeting of APGCC', presentation slides, the $27^{\text {th }}$ meeting of HAPUA Council, Danang, Vietnam, June 23, 2011.

ICEM (2010), 'MRC SEA for Hydropower on the Mekong Mainstream: Energy\& Power Baseline Assessment Working Paper (Volume II)', Energy and Power Baseline Working Paper. Geneva: International Centre for Environmental Management.

IEA (2009a), IEA Scoreboard 2009, Paris: International Energy Agency (www.iea.org).

IEA (2009b), Chile: Energy Policy Review, Paris: International Energy Agency (www.iea.org).

IEA (2011), Key World Energy Statistics 2011, Paris: International Energy Agency (www.iea.org).

Kim, J. and K. Kim (2008), 'The Electricity Industry Reform in Korea: Lessons for Further Liberalization', Mimeo. Graduate School of Public Administration, Seoul National University.

Kumar, A. (2010), 'Electricity Sector in India: Can Markets Work?’, Mimeo LBSNAA, Mussorie, Uttarakhand, India. 
Kwoka, J. (2006), 'Restructuring the U.S. Electric Power Sector: A Review of Recent Studies', Report Prepared for the American Public Power Association, November 2006.

Lovells (2009), Vietnam's Independent Power Producers Sector: Toward Market Liberalisation, Vietnam: Lovells LLP (www.lovells.com).

Meeus, Leonardo and Ronnie Belmans (2008), 'Electricity Market Integration in Europe', $16^{\text {th }}$ PSCC (Power System Computation Conference, Glasgow, Scotland, July 14-16, 2008

Ministry of Power (2012), 'Indian Electricity Scenario', Ministry of Power, Government of India [online]. Available at: http://powermin.nic.in// (accessed August 2012).

Nagayama, H. (2011), 'Japanese Electricity Industry: Recommendations for Restructuring', The Electricity Journal 24(10), 79-90.

Nikomborirak, D. and W. Manachotphong (2007), 'Electricity Reform in Practice: The Case of Thailand, Malaysia, Indonesia and the Philippines', Intergovernmental Group of Experts on Competition Law and Policy, Geneva, 17-19 July.

NSBC (2012), China Energy Statistical Yearbook 2012, Beijing: China Statistics Press.

Poch, K. and S.Tuy (2012), 'Cambodia's Electricity Sector in the Context of Regional Electricity Market Integration', in Yanrui Wu, Xunpeng Shi and Fukunari Kimura (eds) Energy Market Integration in East Asia: Theories, Electricity Sector And Subsidies, ERIA Research Project Report No. 17, chapter 7, Economic Research Institute for ASEAN and East Asia, Jarkata.

Pollitt, M. G. (2005), 'Electricity Reform in Chile: Lessons for Developing Countries', Working Paper 51, Department of Applied Economics, Cambridge: University of Cambridge

Pond, R. (2006), 'Liberalisation, Privatisation and Regulation in the UK Electricity Sector', Working Lives Research Institute, London: London Metropolitan University.

Purra, M. M. (2010), 'Institutional and Regulatory Reform in the Indonesian Electricity Sector: Opportunity or Risk to FDI?', Working Paper series SPP10-13, Singapore: Lee Kuan Yew School of Public Policy.

PWC (2009), Electricity Industry in India USIBC Nuclear Mission. Ahmedabad: Price Waterhouse Coopers, India.

See, Kok Fong (2011), 'Market Reforms and the Performance of the Malaysian Electricity Industry', $\mathrm{PhD}$ Thesis, School of Economics, University of Queensland.

Shen, D. and Q. Yang (2012), 'Electricity Market Regulatory Reform and CompetitionCase Study of the New Zealand Electricity Market', in Yanrui Wu, Xunpeng Shi and Fukunari Kimura (eds) Energy Market Integration in East Asia: Theories, Electricity Sector And Subsidies, ERIA Research Project Report No. 17, chapter 6, Economic Research Institute for ASEAN and East Asia, Jarkata. 
Shi, Y.(2012), 'China’s Power Sector Reform: Efforts, Dilemmas, and Prospects', presentation slides, Development Research Centre, Beijing and Harvard Electricity Policy Group, California, March 8-9, 2012.

Sweeting, A. (2007), 'Market Power in the England and Wales Wholesale Electricity Market 1995-2000, The Economic Journal 117(520), pp.654-87.

Tan, D. (2008), 'Singapore’s Electricity Market after Market Reform', presentation slides, Energy Market Authority, Singapore.

Tanaka, N. (2012), 'Reflecting on Japan’s Energy Policy Review’, Opinion on Energy Policy, Tokyo: Global Energy Policy Research. Available at: http://www.gepr.org/en/contents/20120116-01/

Von Hippel, D., R. Gulidov, V. Kalashnikov and P. Hayes (2011), 'Northeast Asia Regional Energy Infrastructure Proposals’, Energy Policy 39(11), pp.6855-6866.

Wisuttisak, P. (2012), "Regulation and Competition Issues in Thai Electricity Sector", Energy Policy 44, 185-198.

World Bank (2007), Potential and Prospects for Regional Energy Trade in the South Asia Region, Washington, D. C.: The World Bank.

World Bank (2012), World Development Indicators database, Washington, D. C.: The World Bank, (www.worldbank.org).

Xinhua (2011), Country Report on China's Participation in Greater Mekong Subregion Cooperation, Xinhua [online] December 16, 2012. Available at: http://usa.chinadaily.com.cn/china/2011-12/16/content_14279772.htm

Zhai, Y. (2010), 'Energy Sector Integration for Low Carbon Development in Greater Mekong Sub-Region: Towards a Model of South-South Cooperation', World Energy Congress 9.

Zhang, Y.-F., C. Kirkpatrick and D. Parker (2008), 'Electricity Sector Reform in Developing Countries: An Econometric Assessment of the Effects of Privatization, Competition and Regulation', Journal of Regulatory Economics 33(2), pp.159-178. 
ECONOMICS DISCUSSION PAPERS

2010

\begin{tabular}{|c|c|c|}
\hline $\begin{array}{l}\text { DP } \\
\text { NUMBER }\end{array}$ & AUTHORS & TITLE \\
\hline 10.01 & Hendry, D.F. & $\begin{array}{l}\text { RESEARCH AND THE ACADEMIC: A TALE OF } \\
\text { TWO CULTURES }\end{array}$ \\
\hline 10.02 & McLure, M., Turkington, D. and Weber, E.J. & A CONVERSATION WITH ARNOLD ZELLNER \\
\hline 10.03 & $\begin{array}{l}\text { Butler, D.J., Burbank, V.K. and } \\
\text { Chisholm, J.S. }\end{array}$ & $\begin{array}{l}\text { THE FRAMES BEHIND THE GAMES: PLAYER'S } \\
\text { PERCEPTIONS OF PRISONER'S DILEMMA, } \\
\text { CHICKEN, DICTATOR, AND ULTIMATUM GAMES }\end{array}$ \\
\hline 10.04 & Harris, R.G., Robertson, P.E. and Xu, J.Y. & $\begin{array}{l}\text { THE INTERNATIONAL EFFECTS OF CHINA'S } \\
\text { GROWTH, TRADE AND EDUCATION BOOMS }\end{array}$ \\
\hline 10.05 & Clements, K.W., Mongey, S. and Si, J. & $\begin{array}{l}\text { THE DYNAMICS OF NEW RESOURCE PROJECTS } \\
\text { A PROGRESS REPORT }\end{array}$ \\
\hline 10.06 & Costello, G., Fraser, P. and Groenewold, N. & $\begin{array}{l}\text { HOUSE PRICES, NON-FUNDAMENTAL } \\
\text { COMPONENTS AND INTERSTATE SPILLOVERS: } \\
\text { THE AUSTRALIAN EXPERIENCE }\end{array}$ \\
\hline 10.07 & Clements, $\mathrm{K}$. & $\begin{array}{l}\text { REPORT OF THE } 2009 \text { PHD CONFERENCE IN } \\
\text { ECONOMICS AND BUSINESS }\end{array}$ \\
\hline 10.08 & Robertson, P.E. & $\begin{array}{l}\text { INVESTMENT LED GROWTH IN INDIA: HINDU } \\
\text { FACT OR MYTHOLOGY? }\end{array}$ \\
\hline 10.09 & Fu, D., Wu, Y. and Tang, Y. & $\begin{array}{l}\text { THE EFFECTS OF OWNERSHIP STRUCTURE AND } \\
\text { INDUSTRY CHARACTERISTICS ON EXPORT } \\
\text { PERFORMANCE }\end{array}$ \\
\hline 10.10 & Wu, Y. & $\begin{array}{l}\text { INNOVATION AND ECONOMIC GROWTH IN } \\
\text { CHINA }\end{array}$ \\
\hline 10.11 & Stephens, B.J. & $\begin{array}{l}\text { THE DETERMINANTS OF LABOUR FORCE } \\
\text { STATUS AMONG INDIGENOUS AUSTRALIANS }\end{array}$ \\
\hline 10.12 & Davies, M. & $\begin{array}{l}\text { FINANCING THE BURRA BURRA MINES, SOUTH } \\
\text { AUSTRALIA: LIQUIDITY PROBLEMS AND } \\
\text { RESOLUTIONS }\end{array}$ \\
\hline 10.13 & Tyers, R. and Zhang, Y. & APPRECIATING THE RENMINBI \\
\hline 10.14 & Clements, K.W., Lan, Y. and Seah, S.P. & $\begin{array}{l}\text { THE BIG MAC INDEX TWO DECADES ON } \\
\text { AN EVALUATION OF BURGERNOMICS }\end{array}$ \\
\hline 10.15 & Robertson, P.E. and Xu, J.Y. & $\begin{array}{l}\text { IN CHINA'S WAKE: HAS ASIA GAINED FROM } \\
\text { CHINA'S GROWTH? }\end{array}$ \\
\hline 10.16 & Clements, K.W. and Izan, H.Y. & $\begin{array}{l}\text { THE PAY PARITY MATRIX: A TOOL FOR } \\
\text { ANALYSING THE STRUCTURE OF PAY }\end{array}$ \\
\hline 10.17 & Gao, G. & WORLD FOOD DEMAND \\
\hline 10.18 & Wu, Y. & $\begin{array}{l}\text { INDIGENOUS INNOVATION IN CHINA: } \\
\text { IMPLICATIONS FOR SUSTAINABLE GROWTH }\end{array}$ \\
\hline 10.19 & Robertson, P.E. & DECIPHERING THE HINDU GROWTH EPIC \\
\hline 10.20 & Stevens, G. & $\begin{array}{l}\text { RESERVE BANK OF AUSTRALIA-THE ROLE OF } \\
\text { FINANCE }\end{array}$ \\
\hline 10.21 & Widmer, P.K., Zweifel, P. and Farsi, M. & $\begin{array}{l}\text { ACCOUNTING FOR HETEROGENEITY IN THE } \\
\text { MEASUREMENT OF HOSPITAL PERFORMANCE }\end{array}$ \\
\hline
\end{tabular}




\begin{tabular}{|l|l|l|}
\hline 10.22 & McLure, $\mathrm{M}$. & $\begin{array}{l}\text { ASSESSMENTS OF A. C. PIGOU'S FELLOWSHIP } \\
\text { THESES }\end{array}$ \\
\hline 10.23 & Poon, A.R. & $\begin{array}{l}\text { THE ECONOMICS OF NONLINEAR PRICING: } \\
\text { EVIDENCE FROM AIRFARES AND GROCERY } \\
\text { PRICES }\end{array}$ \\
\hline 10.24 & Halperin, D. & $\begin{array}{l}\text { FORECASTING METALS RETURNS: A BAYESIAN } \\
\text { DECISION THEORETIC APPROACH }\end{array}$ \\
\hline 10.25 & Clements, K.W. and Si. J. & $\begin{array}{l}\text { THE INVESTMENT PROJECT PIPELINE: COST } \\
\text { ESCALATION, LEAD-TIME, SUCCESS, FAILURE } \\
\text { AND SPEED }\end{array}$ \\
\hline 10.26 & Chen, A., Groenewold, N. and Hagger, A.J. & $\begin{array}{l}\text { THE REGIONAL ECONOMIC EFFECTS OF A } \\
\text { REDUCTION IN CARBON EMISSIONS }\end{array}$ \\
\hline 10.27 & $\begin{array}{l}\text { Siddique, A., Selvanathan, E.A. and } \\
\text { Selvanathan, S. }\end{array}$ & $\begin{array}{l}\text { REMITTANCES AND ECONOMIC GROWTH: } \\
\text { EMPIRICAL EVIDENCE FROM BANGLADESH, } \\
\text { INDIA AND SRI LANKA }\end{array}$ \\
\hline
\end{tabular}


ECONOMICS DISCUSSION PAPERS

2011

\begin{tabular}{|c|c|c|}
\hline $\begin{array}{l}\text { DP } \\
\text { NUMBER }\end{array}$ & AUTHORS & TITLE \\
\hline 11.01 & Robertson, P.E. & $\begin{array}{l}\text { DEEP IMPACT: CHINA AND THE WORLD } \\
\text { ECONOMY }\end{array}$ \\
\hline 11.02 & Kang, C. and Lee, S.H. & $\begin{array}{l}\text { BEING KNOWLEDGEABLE OR SOCIABLE? } \\
\text { DIFFERENCES IN RELATIVE IMPORTANCE OF } \\
\text { COGNITIVE AND NON-COGNITIVE SKILLS }\end{array}$ \\
\hline 11.03 & Turkington, D. & DIFFERENT CONCEPTS OF MATRIX CALCULUS \\
\hline 11.04 & Golley, J. and Tyers, R. & $\begin{array}{l}\text { CONTRASTING GIANTS: DEMOGRAPHIC CHANGE } \\
\text { AND ECONOMIC PERFORMANCE IN CHINA AND } \\
\text { INDIA }\end{array}$ \\
\hline 11.05 & Collins, J., Baer, B. and Weber, E.J. & $\begin{array}{l}\text { ECONOMIC GROWTH AND EVOLUTION: } \\
\text { PARENTAL PREFERENCE FOR QUALITY AND } \\
\text { QUANTITY OF OFFSPRING }\end{array}$ \\
\hline 11.06 & Turkington, D. & $\begin{array}{l}\text { ON THE DIFFERENTIATION OF THE LOG } \\
\text { LIKELIHOOD FUNCTION USING MATRIX } \\
\text { CALCULUS }\end{array}$ \\
\hline 11.07 & Groenewold, N. and Paterson, J.E.H. & $\begin{array}{l}\text { STOCK PRICES AND EXCHANGE RATES IN } \\
\text { AUSTRALIA: ARE COMMODITY PRICES THE } \\
\text { MISSING LINK? }\end{array}$ \\
\hline 11.08 & Chen, A. and Groenewold, N. & $\begin{array}{l}\text { REDUCING REGIONAL DISPARITIES IN CHINA: IS } \\
\text { INVESTMENT ALLOCATION POLICY EFFECTIVE? }\end{array}$ \\
\hline 11.09 & Williams, A., Birch, E. and Hancock, P. & $\begin{array}{l}\text { THE IMPACT OF ON-LINE LECTURE RECORDINGS } \\
\text { ON STUDENT PERFORMANCE }\end{array}$ \\
\hline 11.10 & Pawley, J. and Weber, E.J. & $\begin{array}{l}\text { INVESTMENT AND TECHNICAL PROGRESS IN THE } \\
\text { G7 COUNTRIES AND AUSTRALIA }\end{array}$ \\
\hline 11.11 & Tyers, R. & $\begin{array}{l}\text { AN ELEMENTAL MACROECONOMIC MODEL FOR } \\
\text { APPLIED ANALYSIS AT UNDERGRADUATE LEVEL }\end{array}$ \\
\hline 11.12 & Clements, K.W. and Gao, G. & QUALITY, QUANTITY, SPENDING AND PRICES \\
\hline 11.13 & Tyers, R. and Zhang, Y. & $\begin{array}{l}\text { JAPAN'S ECONOMIC RECOVERY: INSIGHTS FROM } \\
\text { MULTI-REGION DYNAMICS }\end{array}$ \\
\hline 11.14 & McLure, M. & A. C. PIGOU'S REJECTION OF PARETO'S LAW \\
\hline 11.15 & Kristoffersen, I. & $\begin{array}{l}\text { THE SUBJECTIVE WELLBEING SCALE: HOW } \\
\text { REASONABLE IS THE CARDINALITY } \\
\text { ASSUMPTION? }\end{array}$ \\
\hline 11.16 & Clements, K.W., Izan, H.Y. and Lan, Y. & VOLATILITY AND STOCK PRICE INDEXES \\
\hline 11.17 & Parkinson, M. & $\begin{array}{l}\text { SHANN MEMORIAL LECTURE 2011: SUSTAINABLE } \\
\text { WELLBEING - AN ECONOMIC FUTURE FOR } \\
\text { AUSTRALIA }\end{array}$ \\
\hline 11.18 & Chen, A. and Groenewold, N. & $\begin{array}{l}\text { THE NATIONAL AND REGIONAL EFFECTS OF } \\
\text { FISCAL DECENTRALISATION IN CHINA }\end{array}$ \\
\hline 11.19 & Tyers, R. and Corbett, J. & $\begin{array}{l}\text { JAPAN’S ECONOMIC SLOWDOWN AND ITS } \\
\text { GLOBAL IMPLICATIONS: A REVIEW OF THE } \\
\text { ECONOMIC MODELLING }\end{array}$ \\
\hline 11.20 & $\mathrm{Wu}, \mathrm{Y}$. & $\begin{array}{l}\text { GAS MARKET INTEGRATION: GLOBAL TRENDS } \\
\text { AND IMPLICATIONS FOR THE EAS REGION }\end{array}$ \\
\hline
\end{tabular}




\begin{tabular}{|l|l|l|}
\hline 11.21 & Fu, D., Wu, Y. and Tang, Y. & $\begin{array}{l}\text { DOES INNOVATION MATTER FOR CHINESE HIGH- } \\
\text { TECH EXPORTS? A FIRM-LEVEL ANALYSIS }\end{array}$ \\
\hline 11.22 & Fu, D. and Wu, Y. & $\begin{array}{l}\text { EXPORT WAGE PREMIUM IN CHINA'S } \\
\text { MANUFACTURING SECTOR: A FIRM LEVEL } \\
\text { ANALYSIS }\end{array}$ \\
\hline 11.23 & Li, B. and Zhang, J. & $\begin{array}{l}\text { SUBSIDIES IN AN ECONOMY WITH ENDOGENOUS } \\
\text { CYCLES OVER NEOCLASSICAL INVESTMENT AND } \\
\text { NEO-SCHUMPETERIAN INNOVATION REGIMES }\end{array}$ \\
\hline 11.24 & Krey, B., Widmer, P.K. and Zweifel, P. & $\begin{array}{l}\text { EFFICIENT PROVISION OF ELECTRICITY FOR THE } \\
\text { UNITED STATES AND SWITZERLAND }\end{array}$ \\
\hline 11.25 & Wu, Y. & $\begin{array}{l}\text { ENERGY INTENSITY AND ITS DETERMINANTS IN } \\
\text { CHINA'S REGIONAL ECONOMIES }\end{array}$ \\
\hline & & \\
\hline
\end{tabular}


ECONOMICS DISCUSSION PAPERS

2012

\begin{tabular}{|c|c|c|}
\hline $\begin{array}{l}\text { DP } \\
\text { NUMBER }\end{array}$ & AUTHORS & TITLE \\
\hline 12.01 & $\begin{array}{l}\text { Clements, K.W., Gao, G., and } \\
\text { Simpson, T. }\end{array}$ & $\begin{array}{l}\text { DISPARITIES IN INCOMES AND PRICES } \\
\text { INTERNATIONALLY }\end{array}$ \\
\hline 12.02 & Tyers, R. & $\begin{array}{l}\text { THE RISE AND ROBUSTNESS OF ECONOMIC FREEDOM } \\
\text { IN CHINA }\end{array}$ \\
\hline 12.03 & Golley, J. and Tyers, R. & $\begin{array}{l}\text { DEMOGRAPHIC DIVIDENDS, DEPENDENCIES AND } \\
\text { ECONOMIC GROWTH IN CHINA AND INDIA }\end{array}$ \\
\hline 12.04 & Tyers, R. & LOOKING INWARD FOR GROWTH \\
\hline 12.05 & Knight, K. and McLure, M. & THE ELUSIVE ARTHUR PIGOU \\
\hline 12.06 & McLure, M. & $\begin{array}{l}\text { ONE HUNDRED YEARS FROM TODAY: A. C. PIGOU'S } \\
\text { WEALTH AND WELFARE }\end{array}$ \\
\hline 12.07 & Khuu, A. and Weber, E.J. & HOW AUSTRALIAN FARMERS DEAL WITH RISK \\
\hline 12.08 & Chen, M. and Clements, K.W. & PATTERNS IN WORLD METALS PRICES \\
\hline 12.09 & Clements, K.W. & UWA ECONOMICS HONOURS \\
\hline 12.10 & Golley, J. and Tyers, R. & $\begin{array}{l}\text { CHINA'S GENDER IMBALANCE AND ITS ECONOMIC } \\
\text { PERFORMANCE }\end{array}$ \\
\hline 12.11 & Weber, E.J. & $\begin{array}{l}\text { AUSTRALIAN FISCAL POLICY IN THE AFTERMATH OF } \\
\text { THE GLOBAL FINANCIAL CRISIS }\end{array}$ \\
\hline 12.12 & Hartley, P.R. and Medlock III, K.B. & $\begin{array}{l}\text { CHANGES IN THE OPERATIONAL EFFICIENCY OF } \\
\text { NATIONAL OIL COMPANIES }\end{array}$ \\
\hline 12.13 & $\mathrm{Li}, \mathrm{L}$. & $\begin{array}{l}\text { HOW MUCH ARE RESOURCE PROJECTS WORTH? A } \\
\text { CAPITAL MARKET PERSPECTIVE }\end{array}$ \\
\hline 12.14 & Chen, A. and Groenewold, N. & $\begin{array}{l}\text { THE REGIONAL ECONOMIC EFFECTS OF A REDUCTION } \\
\text { IN CARBON EMISSIONS AND AN EVALUATION OF } \\
\text { OFFSETTING POLICIES IN CHINA }\end{array}$ \\
\hline 12.15 & Collins, J., Baer, B. and Weber, E.J. & $\begin{array}{l}\text { SEXUAL SELECTION, CONSPICUOUS CONSUMPTION } \\
\text { AND ECONOMIC GROWTH }\end{array}$ \\
\hline 12.16 & Wu, Y. & TRENDS AND PROSPECTS IN CHINA'S R\&D SECTOR \\
\hline 12.17 & Cheong, T.S. and Wu, Y. & $\begin{array}{l}\text { INTRA-PROVINCIAL INEQUALITY IN CHINA: AN } \\
\text { ANALYSIS OF COUNTY-LEVEL DATA }\end{array}$ \\
\hline 12.18 & Cheong, T.S. & THE PATTERNS OF REGIONAL INEQUALITY IN CHINA \\
\hline 12.19 & Wu, Y. & $\begin{array}{l}\text { ELECTRICITY MARKET INTEGRATION: GLOBAL } \\
\text { TRENDS AND IMPLICATIONS FOR THE EAS REGION }\end{array}$ \\
\hline 12.20 & Knight, K. & $\begin{array}{l}\text { EXEGESIS OF DIGITAL TEXT FROM THE HISTORY OF } \\
\text { ECONOMIC THOUGHT: A COMPARATIVE } \\
\text { EXPLORATORY TEST }\end{array}$ \\
\hline 12.21 & Chatterjee, I. & $\begin{array}{l}\text { COSTLY REPORTING, EX-POST MONITORING, AND } \\
\text { COMMERCIAL PIRACY: A GAME THEORETIC ANALYSIS }\end{array}$ \\
\hline 12.22 & Pen, S.E. & QUALITY-CONSTANT ILLICIT DRUG PRICES \\
\hline 12.23 & Cheong, T.S. and Wu, Y. & $\begin{array}{l}\text { REGIONAL DISPARITY, TRANSITIONAL DYNAMICS } \\
\text { AND CONVERGENCE IN CHINA }\end{array}$ \\
\hline
\end{tabular}

